J.L.R. Touret ${ }^{1}$, A. G. Bulakh ${ }^{2}$

\title{
THE RUSSIAN CONTRIBUTION TO THE EDIFICATION OF THE NAPOLEON TOMBSTONE IN PARIS
}

${ }^{1}$ IMPMC, Université Pierre et Marie Curie, 4, Place Jussieu, 75005, Paris, France

${ }^{2}$ St Petersburg State University, 7-9, University nab., St Petersburg, 199034, Russian Federation

(Corresponding author: Andrey Bulakh, andreygleb@mail.ru)

The crypt and sarcophagus of Napoleon in the Dôme des Invalids in Paris which were constructed by an Italian-born French architect and designer Louis Tullius Joachim Visconti evince an extraordinarily expressive and harmonic colour combination in French and Italian marbles with those of so called porphyries in Napoleon's tombstone (they are really green andesite from France and purple quartzite from Russia). Works continued over a twenty year period (1840-1861) which saw in France three Kings, one Republic and one Emperor, and in Russia two emperors. Every political change in France exerted critical influence on the continuation of these works. The events surrounding the constructing the crypt and tombstone, applying steam machinery to cut and polish the sarcophagus, the budgets of the work is described from archival documents in detail. J.-F. Bujatti (an Italian from St Petersburg) played an important role in the quarrying of the Russian ornamental stone and in its transport to Paris. Refs 16. Figs 3.

Keywords: Dôme des Invalids, tombstone of Napoleon, L.Visconti, J.-F.Bujatti, Schoksha quartzite.

\section{РУССКИЙ ВКЛАД В СОЗДАНИЕ ГРОБНИЦЫ НАПОЛЕОНА В ДОМЕ ИНВАЛИДОВ В ПАРИЖЕ}

Ж. Л.Р. Туре ${ }^{1}$, А. Г.Булах ${ }^{2}$

${ }^{1}$ Университет Пьера и Марии Кюри, Франция, 75005, Париж, Площадь Жюсье, 4

${ }^{2}$ С.-Петербургский государственный университет,

Российская Федерация, 199034, Санкт-Петербург , Университетская наб., 7-9

Крипта и саркофаг Наполеона в Доме Инвалидов, созданные по проекту родившегося в Италии Л. Висконти, демонстрируют удивительно выразительное и гармоничное по колористическим характеристикам сочетание мраморов из Франции и Италии с так называемыми порфирами гробницы Наполеона (в действительности это андезит из Франции и кварцит из России). Работы длились с 1840 по 1861 год. За это время во Франции сменились три короля, одна Республика и Империя, а в России - два императора. Каждая смена строя и власти во Франции критически сказывалась на их выполнении. События создания крипты и гробницы, применения паровых машин и механизмов для обработки и полировки саркофага, стоимость работ описаны по архивным документам и детально. Особая роль в добыче и доставке камня из России в Париж принадлежит петербургскому итальянцу Ж.-Ф. Буятти. Библиогр. 16 назв. Ил. 3.

Ключевые слова: Дом Инвалидов, гробница Наполеона, Луи Висконти, Ж.-Ф. Буятти, шокшинский кварцит.

\section{Introduction}

The tombstone of Napoleon in the Dôme des Invalides is one of the most visited monuments in Paris, and the sarcophagus made of Russian stone invokes general admiration. It is usually said to be made of porphyry or granite, but both apellations are mistaken, and, moreover, do not explain the artistic sensibility of combining this Russian stone with most famous stone of Italy and France for the decoration of the Dôme des Invalides and the

() Санкт-Петербургский государственный университет, 2016 
making of the tomb. The present paper is based on unpublished documents preserved in the French National Archives [1] and on sources in the literature [2, p. 93-96; 3, p. 61-64; 4, p. 115-117; 5, p. 36-39; 7, p. 79-82; 14, p.4-7; 16, p. 18-20, 56-59]. It describes a unique example of exemplary relations between France and Russia during a twenty-year long period (1840-1861) which saw in France three Kings, one Republic and one Emperor, and in Russia - two Empires.

\section{Discussions in the Deputy Chamber and \\ "Commission des douze"}

As it is well known, King Louis-Philippe, and his Prime Minister Adolphe Thiers, initiated in 1840 a big campaign to repatriate the remains of the former emperor to his home country. The idea to return Napoleon's to Paris provoked a great deal of debate in the Deputy Chamber as to how and where Napoleon should finally be buried. Despite severe criticism, substantial financial resources were allocated by the Chamber: at first 500,000 francs, then, some time later, another 1,500,000 francs. The government appointed a 'Commission des douze' to define the main lines of the monument to be erected and organize an open contest to select its architect. The commission included some of the best artists of the time: J.A.-D. Ingres, painter, and P.-J.D. d'Angers, sculptor, and others. The president was Charles de Rémusat, Deputy, and secretary Théophile Gautier.

The Commission organized a national contest, ruled by law, in April 1840. It attracted no less than 81 architects, whose projects were publicly exhibited in the Palais des Beaux-Arts [11]. On December 21, 1841, the Commission concluded that it was not able to choose any project and left 'to the prudence of the Minister' the choice of the winner. After after long discussions and the withdrawal of one of his members, Delaunay, the commission contented itself to merely define the program that the Minister should follow: an open crypt inside the Dôme, and an equestrian statue outside. In fact, it seems that the careful study of all projects had helped the commission make up its mind, as these recommendations had not been given in the initial proposal of the contest. The Commission had also recommended that all materials be taken on the French territory, a demand enforced by a law voted by the Chamber. Finally the Minister designated two persons, both of Italian origin: the architect Louis Tullius Joachim Visconti (1791-1853) for the monument, the sculptor Carlo Marochetti (1805-1867) for an equestrian statue of Napoleon, in imperial dress, to be placed before the entry of the Dôme.

\section{The project of Louis Visconti}

Around mid-1843, Visconti had fully completed his project, simple, impressive, and technologically risky. The interior of the Dôme des Invalides was occupied by the tombs of Vauban and Turenne, two great personalities of the Ancient Regime, in rather simple marble tombs, weathered and without much decoration. The only real pieces of interest were the magnificent marble mosaics on the floor, ordered by Louvois in 1691 after a drawing by François Lespingola. They were regarded as one of the best examples of 'pietra dura' artwork ever done in France. They were also badly damaged and needed extensive restoration, but Visconti decided that they were worth preserving, at least those, which would not interfere with its new construction. 


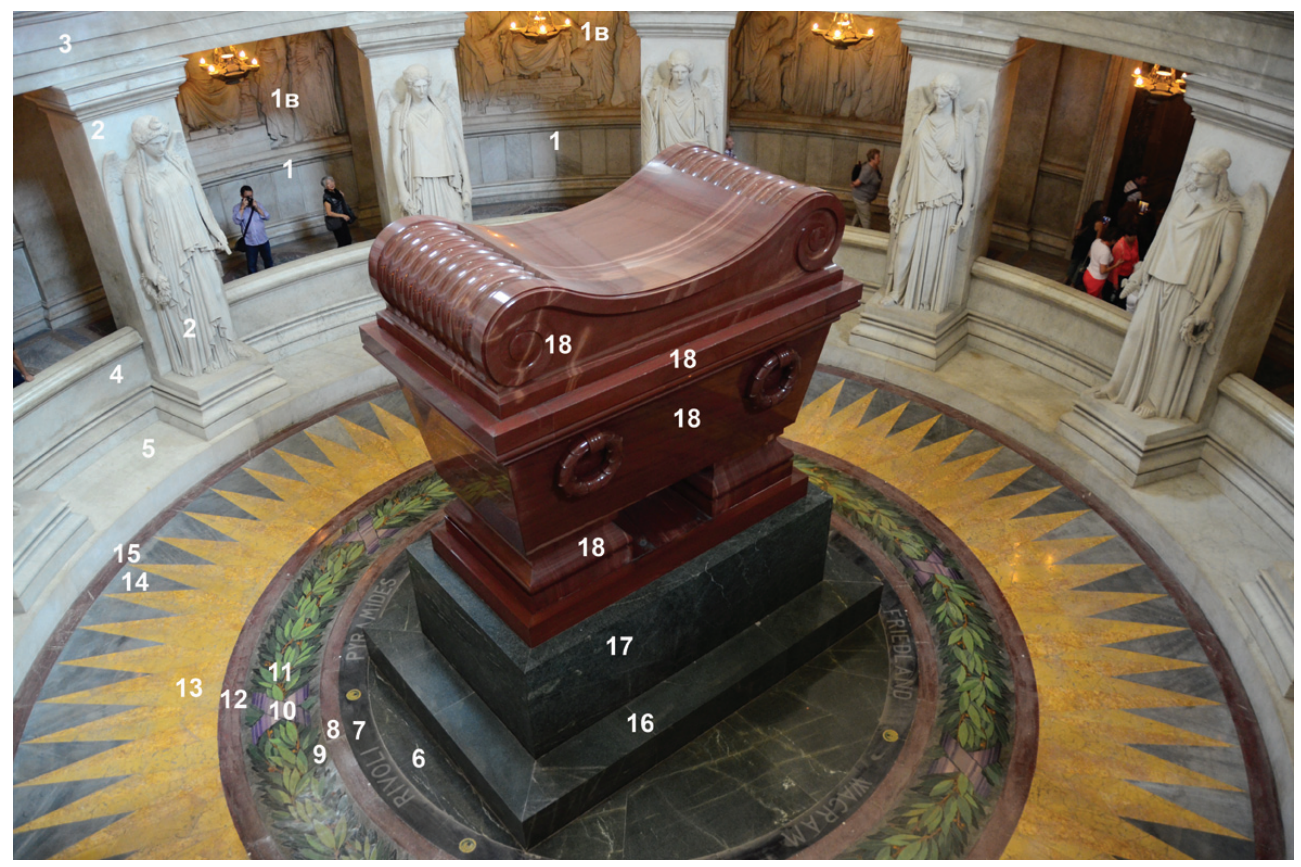

Fig. 1. The crypt and the tombstone of Napoleon

1-5 - Carrara white marbles; $1 \mathrm{~b}$ - Bas reliefs by P.-Ch. Simart; 2 - Statues by J. Pradier; 6, 16, 17 - Mont Thillet (Ternuay, Vosges) green andesite; 7 - black marble "St Lucie"; 8, 10, 12 - red marble "Griotto", presumably from the Pyrenees (Campan); 9, 11, 13 - white marbles incrusted with small colored enamel plates; 14 - Grey marble, presumably "Lunel Fleury" (Boulogne, Northern France); 18 - Purple Shoksha (Russia) quartzite

The tombs of Vauban and Turenne were placed in side chapels, in new monuments, leaving a big open space in the center of the Dôme. There, Visconti took a great risk. He managed to have a huge cavity ( $15 \mathrm{~m}$ diameter on a height of more than 10 meters) dug by hand, without damaging the fragile architecture. The center of the cavity forms a crypt, flanked by galleries. A succession of thick marble slabs was placed at the inner periphery of the crypt. They played a major role in preventing collapse during the deepening of the cavity. Twelve monumental statues, dedicated to an equal number of victories of Napoleon, decorate these plates. Recalling the Caryatides of Ancient Greece, they were carved in situ, not as usual made in separate blocs, and then attached to the wall. The sculptor was James Pradier.

Around the monumental sarcophagus, the base of the crypt is adorned by star-like decorations with bright colors (yellow, to look like the sun, green, blue or violet) (Fig. 1). For these, Visconti developed an entirely new technique, namely incrusting small enamel plates on solid marble. The outer walls of the lower galleries are also covered with marble statues made in bas-relief by Pierre-Charles Simart with the help of a number of assistants (some of their names being inscribed on them). The base of the crypt is connected to the floor of the upper gallery by a large staircase, also in marble (limestone), opening on a monumental door in green "marble", flanked by two bronze statues. Above the door is a black marble plate bearing the famous words that Napoleon wrote in his Memoires, in loose translation: 'I desire my ashes be on the bank of the Seine, among this French people that I have loved so much.' 
A large altar, also in green "marble", is on the edge of the Dôme, on the right hand side of the door to the crypt. It is flanked by 4 monumental, twisted columns, supporting a small ceiling.

\section{Finding suitable materials: The marbles}

Among the critics that Visconti had to face about his projects, some did concern the lines of sarcophagus to be too simple. Visconti replied that the simplicity of the lines was balanced by the preciousness of the materials, and he devoted indeed much energy and much money to selecting the best possible materials. A brilliant 'Ingénieur des Mines', Louis Etienne Héricart de Thury (1776-1854) had been asked in 1810 by the Napoleonic administration to make an inventory of all quarries active on the French territory [13]. It served as a basis for sending letters to Prefects of all departments, asking them if they could find on their territory any rock, which could be used for the monument. The quest was successful for colorful marbles, indeed well represented in many parts of France (the Pyrenees, Alps, Languedoc, Northern France). Two varieties were selected by L. Visconti to make the altar and the entry to the crypt.
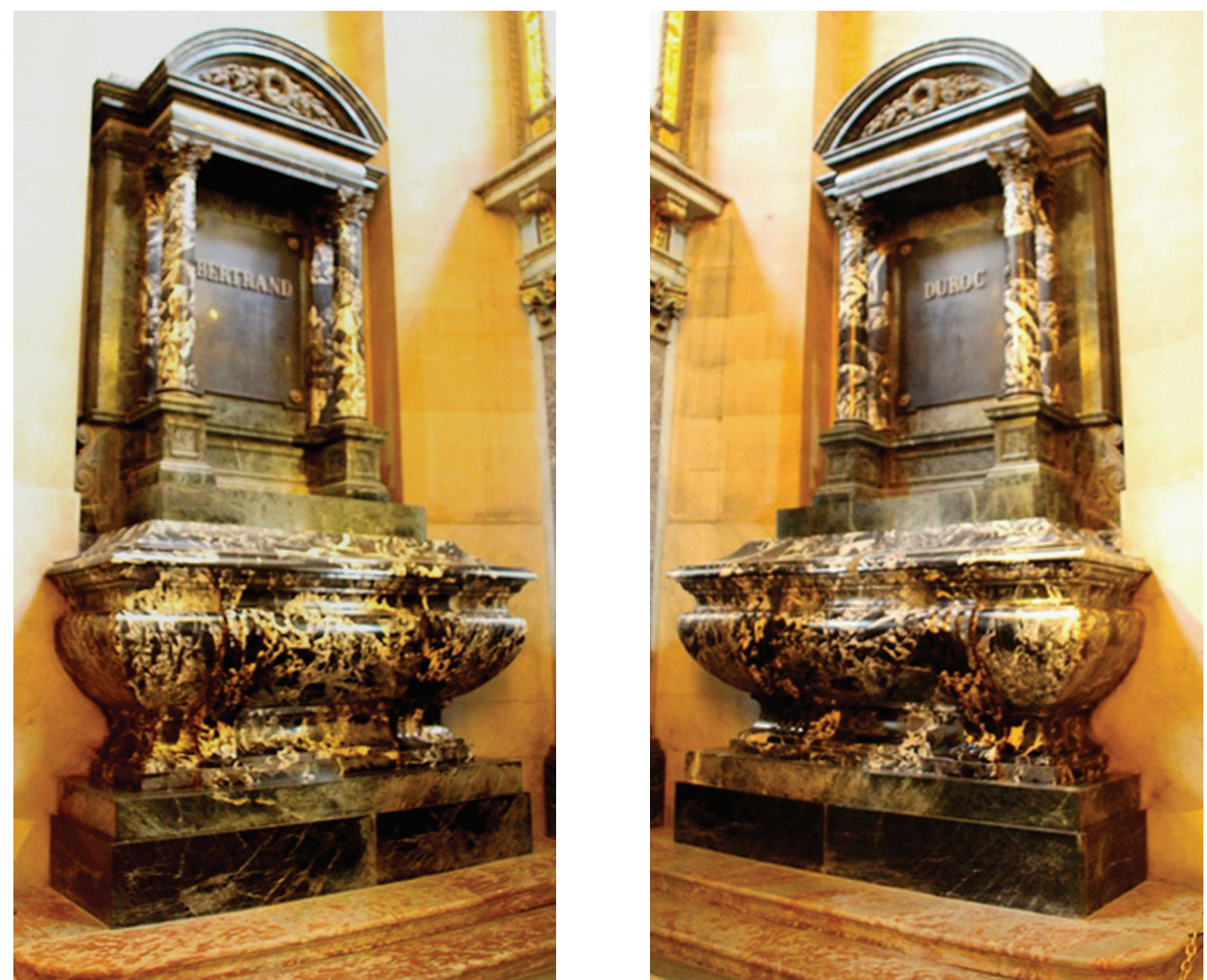

Fig. 2. The Tombstones of Bertrand (left) and Duroc (right)

Marbles "Grand Antique" (columns and tombs), "Brèche Napoléon" (bases of the columns and the top of the tombs), and the black marble is presumably "St Luce" (plates with the names) 
First was a spectacular white and black breccia 'Marbre Grand Antique', which constitutes the 4 monumental columns supporting the baldaquin, a great number of tables and pilasters, as well as the tombstones of two generals of Napoleon, Bertrand and Duroc, in side chapels (Fig. 2). Widely used in Roman times, this marble was for long thought to be lost, but it was rediscovered in the Central Pyrenees at the beginning of the $19^{\text {th }}$ Century. Henri Tarride, from Toulouse (of the firm Tarride, Sons and Company), sent to Paris in 1844 the remarkable amount of about $50 \mathrm{~m}^{3}$ of 'Marbre Grand Antique', from the Aubert quarry, along the valley of the river Lez near Saint Girons, Department of Ariège (Fig. 3, No 9).

The other important colorful 'marble' variety inside the Dôme is a green stone, known under various names (Vert des Alpes, Vert Maurin, Brèche de l'Alpet, Vert d'Egypte) and occurring in large quantities in the Southern French Queyras (Fig. 3, No 7) and the Italian Alps in the Val d'Aoste (Fig. 3, No 5). It is a soft 'ophicalcite', extensively used in the 19th century because of its decorative aspect and facility of use. Approximately the same quantity as 'Marbre Grand Antique' (47 $\mathrm{m}^{3)}$ was sent between 1841 and 1844, by Henry Perroncel (Grenoble), from the Ceillac quarry Queyras (Fig. 3, No 7). H. Perroncel was very proud to have contributed to the monument to Napoleon and changed the name of his rock to 'Brèche Napoléon'. It can be found in many places within the Dôme: the body and walls of the altar, the base of the 'Marbre Grand Antique' columns, the staircase and entry to the door to the crypt, floor decoration in the lower gallery, and so on.

H. Perroncel delivered also the black marble for the plate above the door to the crypt (bearing the words of Napoleon), coming from the Sainte Luce quarry in Isère (Fig. 3, No 6). Few other types of colorful marbles or more common limestone are also found in various places in the Dôme, but in smaller quantities or service areas: e.g. the Campan from the Pyrenees (Fig. 3, No 8), nodular or red marble from Languedoc (Fig. 3, No 10) for the restoration of the floor of the Dôme, Tertiary freshwater limestone from ChateauLandon (Fig. 3, No 3). The mainly grey marble variety of 'Lunel' limestone (or 'Lunel Fleury') from a quarry near Boulogne, in Northern France (Fig. 3, No 1) is used for the steps and bannister to the crypt.

Finally, finding adequate colorful marbles did not pose a major problem. White marble is also not rare in France, and the Direction des Beaux-Arts tried first honestly to find them in the home country. The Direction had on the Ile aux Cygnes, close to the Invalides (at the place of to-day's Musée Branly, now Musée Chirac), a big store (the Département des Marbres), founded by Colbert under Louis XIV, where tons of white marble were available. But none of the size or quality which would satisfy Visconti. A national campaign was launched, resulting in samples sent from the Vosges (Le Chipal), Isère and, especially, the Pyrenees.

Louis Visconti thought that nothing would replace the Carrara marbles, especially for making statues ('statuary marble'). He had a decision from a Commission in the Senate, stating that only the very best materials should be used for the monument, whatever their origin. The necessary condition to have them quarried on the national territory was no longer valid, the law established in 1841 to use only French stones was then abandoned. Understandably, the juicy contract of Carrara marble delivery was the object of severe battles. Finally, the trade would be accounted to the Henraux, 'fournisseur' (supplier), domiciled in Paris, Rue Caumartin 2, for the price of $1200 \mathrm{~F} / \mathrm{m}^{3}$ ! In total, more than $500 \mathrm{~m}^{3}$ marbles of all qualities were delivered 'for the Tombeau de Napoléon' between 


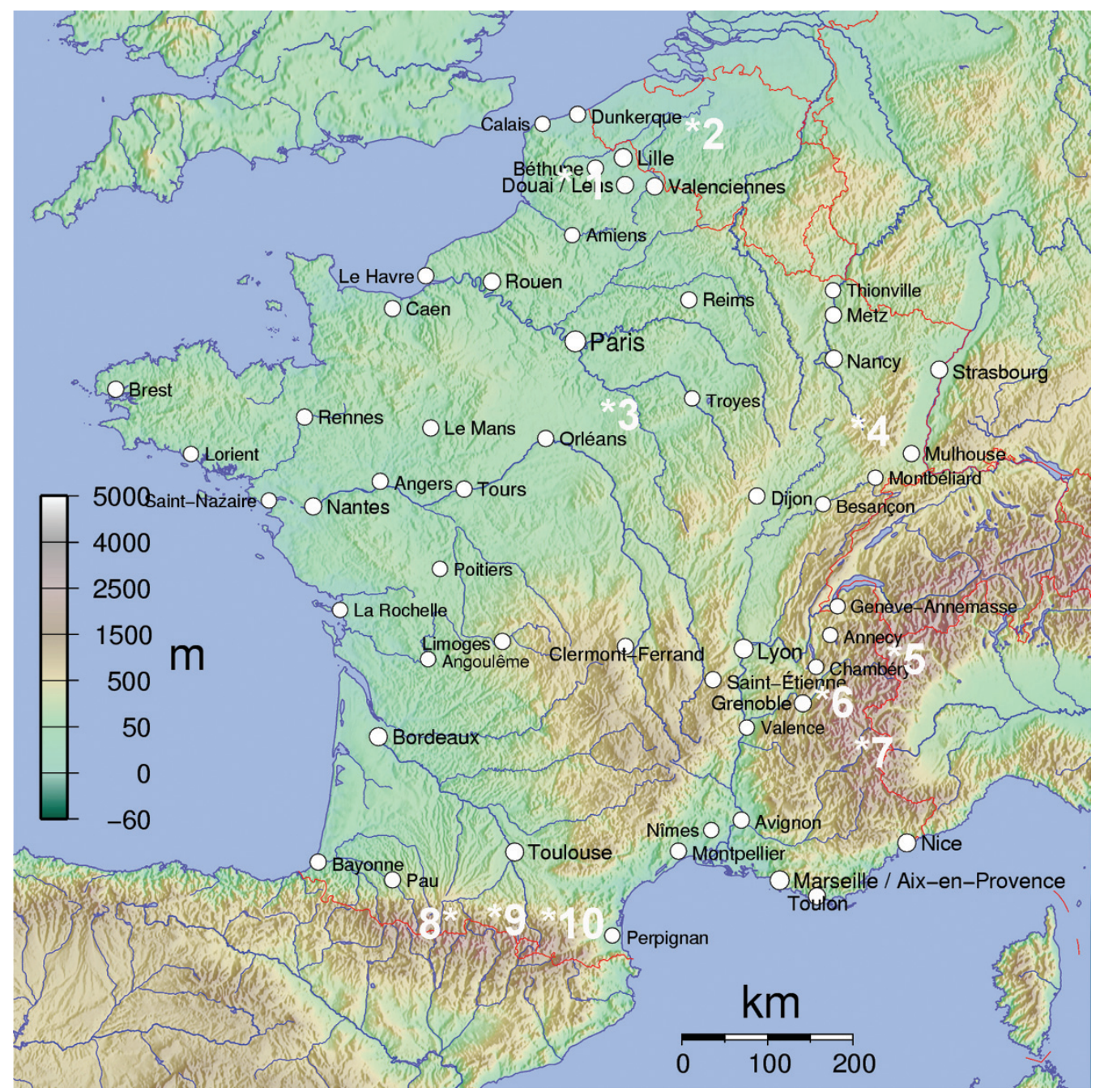

Fig. 3. Approximate locations of quarries (1-10 - explanations are given in the text)

1845 and 1852. All are billed for the standard price of $1200 \mathrm{~F} / \mathrm{m}^{3}$, except for the 'statuary marble, about $10 \%$ in volume, which is more expensive, $2000 \mathrm{~F} / \mathrm{m}^{3}$. Virtually all marbles come from Carrara, except a small quantity of statuary marble supplied in 1845, coming from Serravezza.

In a letter to the Direction des Beaux-Arts (April 24, 1846), Visconti proposed that E. Schwindt would be entirely in charge of the walls of the crypt, and that for the rest of the monument M.Seguin, 12 Rue d'Assas, 'who has just completed the marble work in the baldaquin, to my entire satisfaction'. The work of E. Schwindt was rapidly completed and the crypt entirely stabilized, a real tour de force to have been done without any damage to the Dôme. But Schwindt was not an easy man. The French National Archives have preserved a series of documents in which he requires to be paid extra 'without giving any good reason'. L. Visconti halted further collaboration and gave all responsibility to the marble and granite works to M. Seguin and his workers. 


\section{Hard rocks: Granite and Porphyry}

A key point in L.Visconti's project was that the sarcophagus would be in 'granit', to make the contrast with the surrounding marbles. Geologists and general public may use the same words with a different meaning. For the former, granite is a magmatic rock containing quartz, feldspar and mica, and marble is a metamorphic limestone. But for the latter, the only difference is in the hardness and the ability to be worked out with steel tools: possible for marble, not for granite. The French language makes a difference between these two meanings in the spelling: granite for the geologists, 'granit' (without final $e$ ) for the rest of the world. More precisely, Visconti, according to the recommendation of the "Commission des Douze", thought to the most prestigious types of ancient 'Granits', namely porphyries, either red ('Porfiro Rosso Antico') for the sarcophagus, or green ('Porfiro Verde Antico) for its base.

Red porphyry is by far the most prestigious, it was used in a number of superb statues in antique Rome and Greece. In reality, it is dacite-andesite porphyrite [15, p.203]. The original location had been lost for a long time. In fact, it had been rediscovered few years before (1823), yet the place was so remote and the outcrop of such poor quality than finding suitable rock specimens would have been impossible. French authorities did their utmost best to find suitable material, by sending letters to the Prefects, contacting French embassies abroad, having emissaries sent to Italy and Greece. They did not find red porphyry. Luckily, the situation for the green stone of the base was more successful. .

"Colin \& Son, Epinal" were the first to respond to the request of the Direction des Beaux-Arts for the furniture of the sarcophagus base in green porphyry, offering a price slightly less than $35000 \mathrm{~F}$. Another proposal came from the less known Jean-François Varelle, located at Servance in the Southern Vosges (now Department of Haute-Saône, Fig. 3, No 4). This offer was supported by Héricart de Thury in person, but it had a much higher price, $77000 \mathrm{~F}$. Varelle however had a very good reputation, and the great advantage to live near the place where Vosgian porphyries occur. The price difference was however so significant that Colin was first given the preference.

L. Visconti however had his doubts, and before granting the signature of the minister he wanted to be completely sure that Colin would be able to do a proper work. He wrote several letters to Colin in the course of April and May 1847, stating that he wanted 'green granite' of the darkest hue, identical to a box that he forwarded to Colin. The position of the minister, penciled in black on the letter, is very clear: 'we have no money, take no decision for this year'. The 1848 revolution, which led to the exile of Louis-Philippe, resulted in a complete stop of all work on the monument for nearly one year.

Visconti asked his master of work, Seguin, to go to the Vosges and evaluate the work done in Epinal. Finally Seguin preferred Jean-François Varelle, working at Servance. The place of the quarry is still very visible today. It is situated on the flank of the Mont Tillet, along a steep slope, about $1 \mathrm{~km}$ south of the village of Ternuay. Many loose blocks in the quarry are quite similar to the rock forming the base of Napoleon's sarcophagus.

\section{Stone from Russia}

Once that the question of the pedestal of the sarcophagus had been solved, a major problem remained, namely how to find for the sarcophagus itself a red porphyry which, both in size and quality, could match the 'Porfiro Rosso Antico'. As said earlier, the col- 
lection of Marquis de Drée lists a number of objects in red porphyry issued from various French localities, e.g. Giromani (Giromagny) in the Vosges. It can be supposed that the Service des Mines used this kind of information to search for a suitable rock. But the result being fully negative, more search was done in other countries (Italy, Greece), again in vain. After about two years, L. Visconti was seriously thinking to modify his project, when few samples of a beautiful red rock came to Paris, sent from Russia. The rock was said to be 'Antique Red Porphyry', coming from a place written in Russian and badly understood by the French architects. Later, the correct name will found to be 'Shoksha' (English spelling), in French 'Chokcha'.

The person who took the initiative of sending the rock is not known. Documents in the National Archives say simply 'an engineer', without any detail. It can be speculated that the most Russian of French architects, Auguste Ricard de Montferrand (1786-1858), could have played a role. Slightly younger (by five years) than Louis Visconti, and, like him, a student of Charles Percier at the Ecole Spéciale d'Architecture de Paris, both men certainly knew each other very well. One of his masterworks was the Cathedral of St Isaac in Saint Petersburg, decorated by a great number of granite and marble varieties from all over Russia, Italy and France, Shoksha quartzite is being among them.

Louis Visconti and the Direction des Beaux-Arts had this rock investigated by the best specialist in Paris, Pierre-Louis-Antoine Cordier (1777-1861), professor of geology at the Museum d'Histoire Naturelle. Former student of Dolomieu at the Ecole des Mines, he found rapidly that the rock was not porphyry, but 'a monumental sandstone of the rarest and most beautiful type which, for the quality searched in arts... it offers the rich color of red antique marbles, whose quarries have yet to be recovered....

Comforted by Cordier study, Louis Visconti decided to send a mission to Russia headed by Louis Antoine Léouzon Le Duc (1815-1889), by profession a journalist and who was supposed to know Finland and Russia quite well. Comforted by a substantial amount of money provided by Visconti, Léouzon Le Dud headed for St Petersburg during the summer of 1846. In the book that he wrote few years after his return [9] he tries to convince that he is the sole discoverer of the occurrence of the Shoksha quartzite, after having consulted the Imperial Service of Mines (the richest, most complete in Europe), visited M. Nordensköld, General Director of the Mines in Finland, as well as the masonry workshop in Peterhoff. Then, prospected the whole of Karelia, notably the island of Hogland, to finally discover the place of Shoksha, on the shore of the lake Onega. The reality was much simpler.

The Shoksha quartzite was well known in Russia used since the beginning of the 19th century for the decoration of cathedrals and prestigious monuments. The deposit was described in many details in monographs by the Russian academician V. M. Severgin in 1804 , and by the director of the Imperial Saint-Petersburg mineralogical society professor J. G. Zembnitzkiy in 1834. The first (in 1800) use was for a frieze in the southern facade of St Michael's Castle. Next (in 1810-1811) it was used by the Architect Andrei Voronikhin in the floors of the Cathedral of Our Lady of Kazan [6, p. 32-35, 52]. From 1816, all production was reserved for the construction of the St Isaac cathedral, which would only be completed in 1858 .

L. Léouzon Le Duc took in St Petersburg the service of an Italian engineer, Jean (or Jean-François) Bujatti, established since a long time in Russia. We could not find many traces of Jean-François Bujatti in St Petersburg except a record "Bujatti" in the 
list of persons buried at the so-called Vyborg Roman-Catholic cemetery [12]. There was a Georg Bujatti (1810-1882), who graduated in the Academy of Arts (St Petersburg) in 1844 , then built 7 houses in St Petersburg between 1847-1878 [8, p. 66]. He qualified as an Austrian, but Italy was then under Austrian rule. Maybe this Georg was a brother of Jean-François?

Bujatti found in Shoksha a convenient place to open a new quarry. There are no documents to clear the proportion of his own searching and using of results of earlier Russian prospecting works. But it is known that local entrepreneurs were not ready to accept a newcomer. They tried by all means to cancel the project. L. Léouzon Le Duc understood rapidly that the only way to obtain the permission to open a new quarry would be given by the Tsar Nicolas I in person. He went back to St-Petersburg with Bujatti to reach the private council of the Tsar. Not only was he granted permission, but also the products of the quarry were exempted from all duties and taxes, for an amount evaluated at about 6,000 francs. He did not ask any price for the blocs themselves, which by current market price $\left(2,000 \mathrm{~F} / \mathrm{m}^{3}\right)$ could have amounted to about 80,000 francs. But the French supported all expenses for opening the quarry and moving the blocs, for a total of about 200,000 F.

Nicolas I made thus a generous gesture to France. The support of the Tsar lifted all administrative problems. About $3 / 4$ of the promised $200,000 \mathrm{~F}$ to Léouzon Le Duc were allocated by the French embassy, and Bujatti could start working on a large scale, quarrying hundred's blocs of all size and 'leaving the landscape completely devastated'. Bujatti finally selected 29 blocs to be sent to Paris. The largest was of $4.6 \times 2.9 \times 1.06 \mathrm{~m}$ in size, that he called the 'monolith' and reserved for the cover of the sarcophagus. More than anything, which had been quarried before, for a total volume of $38 \mathrm{~m}^{3}$, whereas the quantity requested by $\mathrm{L}$. Visconti was only $24 \mathrm{~m}^{3}$.

\section{Crisis in Paris}

While Léouzon Le Duc and Bujatti were in Russia, the situation suddenly deteriorated in Paris, to the point that Visconti was very close to being replaced. The credit of 2 million francs that Visconti had received in 1841 had been exhausted for a long time. He had engaged an additional amount of about 600,000 francs without official permission, not a major problem under the permissive administration of King Louis-Philippe. In 1847, he had presented an additional request for a fund of 3 million francs to have the debt covered and the monument fully completed.

But the revolution that occurred on the following year and the new Republican regime (Second Republic) changed completely the situation. The new minister of interior was Alexandre Ledru-Rollin (1807-1874), a leading figure of the opposition who was obviously much less favorable to Napoleon than his predecessors. He appointed a commission, asked to evaluate the state of the work and, above all, propose drastic cost reductions. Visconti had to make a detailed report, saying that 'everything was started, but nothing completed' and finding an excuse for exceeding his budget by the necessity to continue the work and, above all, new requests by the minister, e. g. replace the wooden columns of the baldachin by 'Marbre Grand Antique' or carve the monumental statues by Pradier in solid marble.

The report of the Commission, presented to the minister on May 20, 1848, was devastating, both for Visconti and Léouzon Le Duc, with also severe criticism against the former 
minister, Charles Marie Tanneguy, comte Duchâtel (1797-1875) who, 'while the architect exceeded by 604,000 francs the credit allocated, did not fear to engage 775,000 francs for artwork not mentioned in the budget'. 'In his enthusiasm, Visconti did not find in France, Italy, Greece or Egypt appropriate materials. This poetical hyperbole (sic!) costs France more than 100,000 francs', added the Commission. The mission of Léouzon Le Duc, also due to the 'poetical enthusiasm, of Visconti, did cost to the State 23,239 francs. Then follows a series of criticism against undue costs declared by Léouzon Le Duc, including horse carriages broken and repaired several times, tips and bribes to horse drivers, 'secret funds' given to mysterious 'secret agents', and many others. But there is also criticism of the work itself: the enamel mosaics are an aggression for the eye, the statues by Pradier not worthy of his great name, the equestrian statue by Marochetti lacks expression and monumental character, to cite but a few. The Commission however recognized that the materials, even if too expensive, were of good quality, and it was very laudative about the bas-reliefs by Simart, 'who should be helped by 5 laureates of Rome (pensioneers of Villa Medicis, winners of the yearly Grand Prix de Rome), Joly, Lanno, Ottin, Chambard and Villain'.

Visconti felt obliged to react, and in a long report (47 pages) sent to the minister (Ledru-Rollin) he refuted point by point all critics of the commission. He added then to his report two letters written by recognized authorities, namely Ingres and by Héricart de Thury. No doubt that these letters were of great help to Visconti to avoid threatening sanction, which could have gone toward his replacement. Visconti proposed or accepted some cost reduction, notably to abandon the statue by Marochetti, 'for which more than 100,000 francs had already been spent'. In fact, Visconti had complained that he had been unable to get in touch with Marochetti, but for a very good reason: Marochetti had left Paris to accompany Louis-Philippe in his London exile.

Finally, the commission Ledru-Rollin granted to Louis Visconti a credit of $2,139,000 \mathrm{~F}$. instead of the requested 3 million. A budget cut by about $1 / 3$, which permitted to Visconti to continue his work, but on a minimal scale. Visconti regretted notably that he could not change the glass in windows or make any construction repair to the Dome, work that has been done... in 2006.

\section{The Shoksha quartzite arrives in Paris: unexpected problems}

Bujatti organized the difficult transportation blocks of quartzite to Paris with the help of members of the French embassy in St Petersburg. Tons of rock had to be transported by boat from the lake Onega to the harbor of the city of Kronstadt (Gulf of Finland, Baltic Sea). The boat was taken on the Ladoga Lake in a severe storm, escaping wreckage very narrowly. In Kronstadt, the quartzite was loaded on the Russian frigate L'Hermann, captain Larsen, to Le Havre, which was attained on Jan 6, 1849. Then Bujatti went immediately to Paris, in the hope to be paid and return to St Petersburg. But the operation turned out to be far more difficult than he had expected.

The first problems arose in Le Havre, nobody wanting to cover the costs of moving the blocs from L'Hermann to a smaller riverboat. They were too heavy for the cranes in the harbor, and a complicated system of capstan, used again in Paris, had to be installed. Finally, Bujatti accepted to pay for the transfer, and he understood quickly that his stay in Paris would be much longer that he had hoped. It took only 4 days to the riverboat to be loaded and sail on the Seine. A note of Visconti to the Directeur des Beaux-Arts, dated Jan. 
10,1849 , states that the boat ('challand') carrying the porphyry had just reached the Orsay bridge (facing the Invalides). In total, the travel between the lake Onega to Paris had taken more than 3 months.

The Revolution of 1848 had emptied financial reserves, and the government was in a drastic need of money. A note to the Minister of Interior from the Direction des Beaux-Arts, (Jan. 1849, no day indicated) states that Bujatti should be paid without delay, but that the credits were almost exhausted. But the most urgent question was then to officially receive the blocs of 'Antique Russian Red Porphyry', as they are labeled in the register of the Direction des Beaux-Arts. The reception was done by a special committee of 5 persons, including L. Visconti, J. Bujatti, and three architects. The latest ones examined each bloc in incredible detail, recording any microfracture or damage to the surface. They noted that a number of blocs had been hammered in the quarry, and that in that case a slice of about $5 \mathrm{~cm}$ should be removed to get a clean zone, able to be polished. Instead of $24 \mathrm{~m}^{3}$, this would make a necessary volume of $28 \mathrm{~m}^{3}$, that Bujatti had to furnish without additional costs. Bujatti had brought a total volume of $38 \mathrm{~m}^{3}$, and then he requested $10 \mathrm{~m}^{3}$ to be his own property. This was agreed in principle, but then the architects requested that all blocs be left in the workshop, so that Visconti and Seguin could select the best ones. When the choice had been done, Bujatti was summoned to transport the remaining blocs elsewhere at his own costs, and to pay back a share of the transport costs from Russia!

The agreement sounds a bit dictatorial, but the worst was to come. An obscure employee of the Minister of Finances and the Prefect of Paris 'acting in the name of the people', requested the owner of the blocs (Bujatti) to pay custom rights and special taxes to the town of Paris ('octroi'). Bujatti answered that he found strange to have to pay these rights, as the Tsar had exempted from all taxes in Russia. He also said that he had been promised by L. Léouzon Le Duc to have the same exemption in Paris when signing a contract with him in St Petersburg. After much discussion, Bujatti accepted to pay the custom rights, but not the 'octroi'. He still wanted to dispose of the additional $10 \mathrm{~m}^{3}$ for his own use, 'as the difficulties of extraction and transport, payment delays and a six month stay in Paris have exceeded my expenses beyond any prevision' (Letter to the Minister, April 11, 1849).

But Visconti did not want the 'porphyry' sold in Paris: 'it would be extremely annoying (fâcheux sous tout rapport) that this material would be sold in the commune. Everyone seeing it would immediately think that it comes from the Invalides workshop' Finally, Bujatti accepted that only 5,650 $\mathrm{m}^{3}$ would be paid to him, for about 5,620 F, much less that he would have obtained by selling the rocks on open market. Few samples were deposited in the mineralogical collections in Paris, in the Musée d'Histoire Naturelle and in the Ecole des Mines. The rest was used for making various objects and large vases, one exhibited in the Musée de l'Armée, another containing the heart of Gambetta in the Panthéon.

\section{Nothing like this had been done since Ancient Egyptians}

When Louis-Napoléon Bonaparte was elected president of the Second Republic on 10 December 1848 the stone for the monument was there, but the Chamber had reluctantly voted additional financing, and everything was now ready for it to be finalized. The major problem was evidently to make the sarcophagus, which by the size of the blocs and 
hardness of the rocks exceeded anything having been done previously. Only the Ancient Egyptians and, to a lesser extent, the Romans had cut and polished granites of comparable dimensions. The technique had practically not changed since their time.

Seguin made a very detailed estimate of the work to be done, and he discovered rapidly that it would be completely impossible to maintain the deadline by conventional techniques: 'preparation of a flat surface of $3.91 \mathrm{~m}^{2}$ requires 115 worker days and reforming 3103 tool heads. A rosette (corner sculpture) only barely indicated (à peine ébauchée), of a diameter of $64 \mathrm{~cm}$ needs 45 days of a most experienced worker (habile ouvrier) and reforming of 6,000 heads'. Steam machines (and railroads) were then in full development, and Seguin proposed to install in the workshop a steam 'machine equivalent to 6 or 7 horses'. He asked the assistance of 'the best specialist in Paris', that he names in one of his letters 'M. Mouille', but making such a machine was a very difficult task.

After 4 months, the steam machine was not operative, and Visconti started to be seriously worried. Finally, 3 steam machines would be completed with a total 60 horse power, a remarkable power for the time, and would work to the entire satisfaction of Seguin and Visconti. The use of steam machine for granite working was a true technological revolution, until a next one which took place about a century later, namely the widespread use of diamond tools.

\section{Opening the monument}

It took about two years to make the sarcophagus, a true masterpiece of granit working. After 130 years, the polish is still almost perfect and the rock unchanged, except for few yellowish strips on the top of its cover. By the end of 1853 it was almost finished, ready to receive the remains of Napoléon and his seven coffins. Yet the official ceremony would take place only 8 years later, on 2 April 1861. One reason is the sudden death of Louis Visconti from heart attack on 2 December 1853, just after having been elected to the Academie des Beaux-Arts. But another architect, Jules Bouchet, followed by Jules Crépinet in 1860, immediately replaced him. The official reason for the delay is the time spent on the enamel mosaics of the floor of the crypt and, above all, on the marble statues and bas-relief of the lower galleries. J. Pradier died also prematurely in 1852, before he could - or wanted - to finish the monumental Caryatid statues. All statuary work for the tombstone of Napoleon will then be completed by P.-Ch. Simart, who, despite the help of the Roman laureates took years to finish his bas-reliefs, 12 in total. At the time of the inauguration, one was still not finished; it had to be replaced in great hurry by a model in plaster.

But the real reason of such a delay is elsewhere. Napoleon III was not satisfied, either by the monument itself ('Visconti was a good architect, but this time he was wrong', a remark reported by A. Ettex in his memories), or by its emplacement. He wanted to establish his dynasty by burying his entire lineage in the Basilica of Saint Denis, like the kings of France. He asked even Eugène Viollet le Duc to conceive a project, a gothic church near the basilica, but he retreated, fearing too much protest from the public.

The ceremony of April 1861 was minimal, led by the Archbishop of Paris in the presence of Napoleon III and his family. No Corps Diplomatique, no representative of Russia. Alexander II, successor of Nicolas I, came to Paris in 1867, at the occasion of a Universal Exhibition. But he had hardly the time to visit the tombstone of Napoléon, being wounded 
in Longchamp in the company of Napoleon III. Only Alexander III, at the occasion of the inauguration of the magnificent bridge bearing his name in 1900, could have a look to the monument and admire a sarcophagus of a red Russian rock type. In 2008, the magnificent marble mosaics on the floor, ordered by Louvois in 1691 on a drawing of Lespingola were restored, and they are the only piece of 'Grand Siècle' time remaining inside the Dôme.

\section{Conclusions}

Visitors to the Dóme des Invalids admire the strawberry-red color of the stone of sarcophagus which is a kind of symbol of the tradition of friendship between France and Russia, despite all the political difficulties. The Tomb of Napoleon has survived all the threats of two world wars; it remains one of the most visited monuments in Paris today. It has preserved all the marks of the great talent of L. Visconti, J.Pradier, P.-Ch. Simart and the delicately felt beauty of the stones and harmony of their colors. And a special role to mine and to bring the red Russian stone belongs to Jean-François Bujatti.

\section{Acknowledgments}

JT addresses his thanks to Jacques Macé (Etudes Napoléoniennes), Jean-Paul Gremilliet and Cyrille Delangle (Terrae Genesis), AB thanks Anatoly Zolotarev, Svetlana Kornilova, Victoria Kondratyeva, Professor Alexey Brusnisyn, and especially to Dr Andrey Ukhanov who had read and discussed the manuscript.

\section{References}

1. French National Archives (Peyrefitte, Dossiers NN F/21/477, F/21/559, F/21/730, F/21/732, F/21/739).

2. Bulakh A. G. Kamennoe ubranstvo Peterburga. Etiudy o raznom [Stone decoration of St Petersburg. Essays]. St Petersburg, Sudarynia Publ., 1999, 150 p. (In Russian)

3. Bulakh A. G., Voevodsky I.E. Kamennoe ubranstvo Peterburga. Porfir i mramor, i granit... [Stone decoration of St Petersburg. Porphyry and marble, and granite...]. St Petersburg, Eklektika Publ., 2007, 158 p. (In Russian)

4. Bulakh A. G. "Porphyries" from Russia and Sweden used in St Petersburg and Russian "porphyry" used in Paris: misuse of geological terms for a possible candidate as a Global Heritage Stone Resource. Episodes. J. of Intern. Geosciences, 2015, vol.38, no. 2, pp. 114-117. Available at: http://www.episodes.co.in (accessed 06.05.2016).

5. Bulakh A. G. Russkii porfir v Parizhe i shvedskii v Peterburge. Mify i real'nost' [Russian porphyry in Paris and Swedish porphryr in St Petersburg: Myths and realities]. St Petersburg University, 2015, vol. 28, no. 1 (3886), pp.36-39, 114-116. Available at: http://journal.spbu.ru (accessed 06.05.2016). (In Russian)

6. Bulakh A. G. Po vole razuma i chuvstv. Sankt-Peterburg - Khel'sinki. Dva pravoslavnykh kafedral'nykh sobora [Under influence of mind and senses. St Petersburg - Helsinki. Two orthodox cathedrals]. St Petersburg, St Petersburg University Press, 2016, 82 p. Available at: http://minsoc.ru/FilesBase/Bulakh2015.pdf (accessed 06.05.2016). (In Russian)

7. Bulakh A. G., Gavrilenko V. V., Panova E. G. Malinovyi shokshinskii kvartsit [Crimson red schoksha quartzite]. Mineral, 1999, no. 2, pp.79-82. (In Russian)

8. Ginzburg A.M., Kirikov B. M. Arkhitektory-stroiteli Sankt-Peterburga serediny XIX - nachala XX veka [Architects-builders of Saint Petersburg in the mid-19 $9^{\text {th }}$ early $20^{\text {th }}$ century]. Handbook. St Petersburg, Piligrim Publ., 1996, 396 p. (In Russian)

9. Leouzon le Duc. Le sarcophage de Napoléon en son tombeau des Invalides. Paris, 1873. Available at: http://gallica.bnf.fr/ark:/12148/bpt6k114587g (accessed 06.05.2016).

10. Noël P. Les carrières françaises de pierre de taille. Société de diffusion des techniques du bâtiment et des travaux publics. Paris, 1970. 
11. Notice historique sur le palais des Beaux-Arts: Exposition des projets ou plans pour le tombeau du Grand Napoléon, noms des artistes admis au concours pour cet important objet, Description des tableaux qui sont à l'intérieur de l'Ecole. Paris, 1841. Available at: http://gallica.bnf.fr/ark:/12148/bpt6k63780433 (accessed 06.05.2016).

12. Pozarski O.K. Rzymskokatolicki Cmentarz Wyborski w Sankt Petersburgu (1856-1950). Ksiega Pamieci. St Petersburg - Warsaw, 2003.

13. Thury (Hericart de Thury). Rapport sur l'état actuel des carrières de marbre. Annales des Mines, 1823, Série 1, vol. 8, pp. 2-96. Mei. 4-7.

14. Touret J., Nijland T. G. Het graf van Napoléon in de Dome des Invalides in Parijs. Geol. Brief, 2016,

15. Price M. T. The Sourcebook of Decorative Stone. Quinlet Publishing Limited, 2007, 288 p.

16. Ziskind M.S. Dekorativno-oblitsovochnye kamni [Decorative Dimension Stone]. Moscow, Nedra Publ., 1989, 258 p. (In Russian)

For citation: Touret J.L.R., Bulakh A. G. The Russian contribution to the Edification of the Napoleon Tombstone in Paris. Vestnik of Saint Petersburg University. Series 15. Arts, 2016, issue 3, pp. 70-83. DOI: $10.21638 / 11701 /$ spbu15.2016.306

Статья поступила в редакцию 12 мая 2016 г.

Контактная информация:

Touret Jacques Leon Robert — Professor Emeritus; jacques.touret@impmc.upmc.fr

Bulakh Andrey G. - Professor; andreygleb@mail.ru 